\title{
DESAIN STRUKTUR SHELTER INOVATIF SEBAGAI TEMPAT EVAKUASI SEMENTARA DI BANYUWANGI
}

\author{
Ade Fani S. I. '), Mirza Ghulam Rifqi' ${ }^{1)}$, Zulis Erwanto'), dan M. Shofi'ul Amin') \\ 1) Jurusan Teknik Sipil, Politeknik Negeri Banyuwangi, Banyuwangi, Jawa Timur \\ mirza@poliwangi.ac.id
}

\begin{abstract}
In 1994 the tsunami in Banyuwangi affected 4 regions namely Pancer, Lampon, Rajegwesi, Grajagan with an earthquake magnitude of 7.5, this requires that disaster-prone areas in Banyuwangi must have an evacuation infrastructure for natural disasters and emergency plans. This study aims to plan an innovative shelter structure design based on temporary evacuation sites in Banyuwangi. The planning used in designing this shelter is to review the structure of columns, beams, plates, and raft foundations, the design of the structure used is steel structure made following the provisions of the load and durability factor design (DFBK) using computer applications that refer to SNI 03-1726-2019, SNI 031729-2015, SNI 03-1727-2013, and FEMA P646A. Based on the planning results, an innovative shelter with dimensions of $16 \mathrm{~m} \times 4 \mathrm{~m} \times 3.5 \mathrm{~m}$, on the beam using IWF 350.350.19.19 steel profile and the column using IWF 350.350.19.19 with a weight of the shelter structure of $38292.9 \mathrm{Kg}$. The results of the beam structure planning with the control of flexural and shear interaction checks were $1.19<1.375$, the column structure planning with the control of the design compressive strength was $0.228<1$. The foundation of the raft is planned with dimensions of $16 \mathrm{~m} 4 \mathrm{~m}$ and it is recommended that the thickness is $80 \mathrm{~cm}$ with pressure control on the ground of $0.061 \mathrm{Kg} / \mathrm{cm}^{2}<0.188 \mathrm{Kg} / \mathrm{cm}^{2}$.
\end{abstract}

Keywords: Banyuwangi, shelter, steel structure, temporary evacuation site, tsunami 


\begin{abstract}
ABSTRAK
Pada tahun 1994 kejadian tsunami di Banyuwangi berdampak pada 4 daerah yakni Pancer, Lampon, Rajegwesi, Grajagan dengan magnitudo gempa sebesar 7.5, hal ini menuntut kawasan rawan bencana di Banyuwangi harus memiliki infrastruktur evakuasi untuk bencana alam dan emergency plan. Penelitian ini bertujuan untuk merencanakan desain struktur shelter inovatif berbasis tempat evakuasi sementara di Banyuwangi. Perencanaan yang digunakan dalam mendesain shelter ini adalah dengan meninjau struktur kolom, balok, pelat, dan pondasi rakit, desain struktur yang digunakan adalah struktur baja dibuat sesuai dengan ketentuan desain faktor beban dan ketahanan (DFBK) dengan menggunakan aplikasi komputer yang mengacu pada SNI 03-1726-2019, SNI 03-17292015, SNI 03-1727-2013, dan FEMA P646A. Berdasarkan hasil perencanaan, Shelter inovatif dengan dimensi $16 m \times 4 m \times 3.5 \mathrm{~m}$, pada balok menggunakan profil baja IWF 350.350.19.19 dan kolom menggunakan IWF 350.350.19.19 dengan berat struktur shelter sebesar $38292.9 \mathrm{Kg}$. Hasil perencanaan struktur balok dengan kontrol pemeriksaan interaksi lentur dan geser sebesar $1.19<1.375$, perencanaan struktur kolom dengan kontrol pemeriksaan kekuatan tekan desain sebesar $0,228<1$. Pondasi rakit direncanakan dengan dimensi $16 \mathrm{~m} \times 4 \mathrm{~m}$ dan disarankan dengan ketebalan $80 \mathrm{~cm}$ dengan kontrol tekanan pada tanah sebesar $0.061 \mathrm{Kg} / \mathrm{cm}^{2}<0.188 \mathrm{Kg} / \mathrm{cm}^{2}$.
\end{abstract}

Kata kunci: Banyuwangi, shelter, struktur baja, tempat evakuasi sementara, tsunami 


\section{PENDAHULUAN}

Badan Nasional Penanggulangan Bencana (BNPB) membagi daerah-daerah di Indonesia menurut tingkat resiko bencana dalam buku Penurunan Risiko Bencana Indonesia, wilayah Banyuwangi memiliki tingkat risiko bencana salah satu yang terbesar di wilayah Jawa Timur dengan indeks risiko bencana sebesar 219.2. Pada tahun 1994 kejadian tsunami di Banyuwangi berdampak pada 4 daerah dengan magnitudo gempa sebesar 7.5 dan setidaknya 238 korban jiwa pada daerahdaerah tersebut (Anonim, 2016). Hal ini menuntut kawasan rawan bencana di Banyuwangi harus memiliki infrastruktur evakuasi untuk bencana alam dan emergency plan.

Pada tahun 2012 BNPB menggalakkan masterplan pengurangan risiko bencana tsunami dengan sasaran utama adalah tersedianya Tempat Evakuasi Sementara (TES) pada kawasan dengan tingkat risiko tinggi tsunami, namun pada saat ini menurut Kapusdatin BNPB kebutuhan shelter atau TES masih sangat kurang, dari bangunan shelter yang ada di Indonesia sebagian besar tidak layak, dan tidak terawat sehingga menyebabkan bangunan tersebut tidak terpakai atau mangkrak.
Bangunan shelter yang tidak terpakai adalah bangunan yang memiliki satu tujuan atau single purpose hanya untuk penyelamatan pada saat terjadi bencana tsunami. Pada tahun 2012 Brahman Industries telah menciptakan tempat evakuasi yang hanya untuk mitigasi bencana badai, tornado, dan tsunami yang dinamai STATIM Shelter. Pada penelitian ini bertujuan untuk merencanakan desain struktur shelter inovatif berbasis tempat evakuasi sementara di Banyuwangi. Shelter didesain untuk multifungsi atau multi purpose, dapat digunakan sehari-hari dan difungsikan sebagai pusat kesehatan khusus atau unit perawatan intesif untuk nelayan atau warga sekitar yang mengalami kecelakaan sebagai pertolongan pertama. Untuk memenuhi kebutuhan listrik didalam shelter, digunakan panel surya yang memanfaatkan energi matahari, serta terdapat fasilitas keselamatan yang cukup lengkap untuk tujuan utama dari shelter.

\section{KAJIAN PUSTAKA}

Berdasarkan Federal Emergency Management Agency (FEMA) tentang vertical evacuation from tsunamis: A guide for community officials, struktur bangunan tempat evakuasi sementara tidak harus bertahan dari gelombang tsunami dan hantaman puing-puing saja, bangunan juga 
harus bertahan akibat gempa bumi dan masih dapat berfungsi kembali. Struktur seharusnya tidak menampakkan kerusakan akibat gempa bumi karena orang akan takut untuk masuk ke bangunan, sebagai contoh, kerusakan yang besar pada dinding atau akibat kerusakan yang lain (Anonim, 2009a).

Tempat evakuasi sementara bukan merupakan tempat evakuasi akhir, tetapi fasilitas umum yang dapat dijangkau oleh para penyintas (survivor) dalam beberapa menit setelah peringatan terjadinya tsunami diumumkan, lokasinya tidak jauh dari pantai (minimal 500 meter). Selain itu bangunan juga harus memenuhi syarat dengan menggunakan konstruksi tahan gempa karena pada umumnya tsunami didahului dengan gempa bumi dan gempa susulan (Hutapea, 2019).

\subsection{Tempat Evakuasi Sementara (TES)}

Tempat evakuasi sementara merupakan tempat evakuasi yang digunakan sementara selama bencana gempa bumi atau tsunami dan letaknya dapat menjangkau terdampak bencana untuk menyelamatkan nyawa manusia, dimana setelah masa kritis telah usai para penyintas dapat menuju ke tempat evakuasi akhir yang tempatnya jauh dan aman.
Proses evakuasi merupakan cara tanggap darurat dan persiapan darurat, sehingga pertimbangan mitigasi yang utama adalah menentukan lokasi, mendesain, dan membangun bangunan yang dapat menahan gaya-gaya tsunami yang diperkirakan dan guncangan tanah akibat gempa (Rifqi, Amin, \& Sandi, 2019).

\subsection{Baja}

Desain harus dibuat sesuai dengan ketentuan Desain Faktor Beban dan Ketahanan (DFBK) atau dengan ketentuan untuk Desain Kekuatan Izin (DKI). Berdasarkan definisinya, desain DFBK sebenarnya memberikan hasil desain yang lebih optimum karena telah mempertimbangkan interaksi antara kekuatan material dan beban. Namun, desain DFBK ini di lain pihak menuntut ketepatan dan kecermatan dalam proses fabrikasi maupun erection. Desain DFBK yang semakin optimum memiliki faktor keamanan yang kecil sehingga semakin sedikit ruang yang diberikan untuk kesalahan. Maka perencanaan bangunan shelter menggunakan metode Desain Faktor Beban dan Ketahanan (DFBK) (Anonim, 2015b).

Desain yang sesuai dengan ketentuan untuk desain faktor beban dan ketahanan (DFBK) memenuhi persyaratan spesifikasi ini bila kekuatan desain setiap komponen 
struktural sama atau melebihi kekuatan perlu yang ditentukan berdasarkan kombinasi beban DFBK. Desain dapat ditentukan sesuai dengan persamaan 1:

$$
\mathrm{R}_{\mathrm{u}}<\varnothing \mathrm{R}_{\mathrm{n}}
$$

\subsection{Pembebanan}

Pembebanan yang direncanakan sesuai SNI 1727 tahun 2013 tentang beban minimum untuk perancangan bangunan gedung dan struktur lain, adapun pembebanan yang ditinjau pada shelter antara lain : beban mati, beban hidup, beban angin, beban gempa, beban tsunami (Anonim, 2013).

Menurut FEMA P646 tahun 2009 mengemukakan gaya-gaya yang harus diperhitungkan dalam desain bangunan agar dapat menahan gelombang tsunami diantaranya meliputi (Anonim, 2009a):

\subsubsection{Gaya Hidrodinamik}

Saat air mengalir disekeliling bangunan/struktur, gaya hidrodinamis dikenakan terhadap struktur tersebut sebagai keseluruhan ataupun masingmasing komponen struktur, gaya ini dipengaruhi oleh massa jenis air, kecepatan aliran dan bentuk struktur. Gaya hidrodinamis ini dapat dihitung dengan Persamaan 2:

$$
\mathrm{F}_{\mathrm{d}}=1 / 2 \cdot \rho_{\mathrm{s}} \cdot \mathrm{C}_{\mathrm{d}} \cdot \mathrm{B} \cdot\left(\mathrm{h}_{\mathrm{u}}{ }^{2}\right)_{\text {max }}
$$

Untuk gaya pada masing-masing komponen struktur, B diambil dari lebar komponen. Direkomendasikan koefisien tarik yang digunakan $\mathrm{Cd}=2.0$. Resultan gaya hidrodinamis dikenakan pada tengahtengah bidang terendam dari komponen. Gaya hidrodinamis ini harus berdasarkan kepada parameter $\left(\mathrm{h}_{\mathrm{u}}{ }^{2}\right)_{\max }$, yang merupakan momentum flux maksimum per unit massa pada lokasi pada setiap waktu saat tsunami terjadi. Parameter tersebut dapat diestimasi menggunakan Persamaan 3:

$$
\begin{aligned}
& \left(h u^{2}\right)_{\max }=g \cdot R^{2}\left(0.125-0.235\left(\frac{Z}{R}\right)\right. \\
& +0.11\left(\frac{\mathrm{z}}{\mathrm{R}}\right)^{2} \text { ) }
\end{aligned}
$$

\subsubsection{Gaya Impulsif}

Gaya impulsif disebabkan oleh muka limpasan air yang menabrak struktur. Besar gaya impulsif terhadap bangunan adalah 1.5 kali gaya hidrodinamis, sehingga direkomendasikan penghitungan gaya impulsif ini menggunakan Persamaan 4:

$$
\mathrm{F}_{\mathrm{s}}=1.5 \times \mathrm{F}_{\mathrm{d}}
$$

\subsubsection{Gaya Tumbukan Debris atau Hanyutan Puing}

Gaya tumbukan dari puing-puing hanyutan (semisal: batang pohon, kapal, mobil, dan lain-lain) dapat menjadi faktor terbesar penyebab kerusakan pada bangunan. Namun hal ini sulit, untuk memperkirakan secara akurat gaya yang disebabkan oleh tumbukan ini. Gaya 
tumbukan oleh puing hanyutan ini dapat diperkirakan dengan menggunakan Persamaan 5:

$$
\mathrm{F}_{\mathrm{i}}=\mathrm{C}_{\mathrm{m}} \cdot \mathrm{U}_{\max } \sqrt{(\mathrm{k} \cdot \mathrm{m})}
$$

\subsubsection{Gaya tahanan debris atau hanyutan puing}

Efek tahanan yang disebabkan oleh akumulasi puing-puing hanyutan yang tersangkut pada struktur dapat diperlakukan sebagai gaya hidrodinamik tambahan oleh puing yang tertahan struktur. Persamaan berikut adalah modifikasi dari rumus hidrodinamis yang memasukkan lebar tahanan dari puing.

Gaya tahanan debris atau hanyutan puing dapat diperkirakan dengan Persamaan 6:

$$
\mathrm{F}_{\mathrm{dm}}=1 / 2 \cdot \rho_{\mathrm{s}} \cdot \mathrm{C}_{\mathrm{d}} \cdot \mathrm{B}_{\mathrm{d}} \cdot\left(\mathrm{hu}^{2}\right)_{\text {max }} \cdots(6
$$

\subsection{Kombinasi Pembebanan}

Berdasarkan peraturan pembebanan SNI 03-1727-2013 dan peraturan ketahanan gempa SNI 03-1726-2019. Struktur, komponen, dan fondasi harus dirancang sedemikian rupa sehingga kekuatan desainnya sama atau melebihi efek dari beban terfaktor dalam kombinasi berikut (Anonim, 2013; Anonim, 2019):

1. $\quad 1.4 \mathrm{D}$

2. 1.2 D + 1.6 L + $0.5(\mathrm{Lr}$ atau $\mathrm{S}$ atau R)
3. $1.2 \mathrm{D}+1.6(\mathrm{Lr}$ atau $\mathrm{S}$ atau $\mathrm{R})+$ (L atau $0.5 \mathrm{~W}$ )

4. $1.2 \mathrm{D}+1.0 \mathrm{~W}+\mathrm{L}+0.5(\mathrm{Lr}$ atau $\mathrm{S}$ atau $\mathrm{R}$ )

5. $1.2 \mathrm{D}+1.0(\mathrm{Ev}+\mathrm{Eh})+\mathrm{L}+0.2$ $\mathrm{S}$

6. $0.9 \mathrm{D}+1.0 \mathrm{~W}$

7. $0.9 \mathrm{D}-1.0(\mathrm{Ev}+\mathrm{Eh})$

Kekuatan tsunami akan berpengaruh pada seluruh struktur dan setiap member struktur harus dihitung, dan kekuatan member yang dihasilkan kemudian harus dikombinasikan dengan beban gravitasi berdasarkan Desain Faktor Beban dan Ketahanan (DFBK):

1. $1.2 \mathrm{D}+1.0 \mathrm{LREF}_{\mathrm{REF}}+0.25 \mathrm{~L}$

2. $0.9 \mathrm{D}+1.0 \mathrm{Ts}$

\subsection{Desain Pondasi Rakit}

Pondasi rakit digunakan bila susunan kolom-kolom jaraknya sedemikian dekat disemua arahnya, sehingga bila dipakai pondasi telapak, sisi-sisinya berhimpit satu sama lain. Pondasi rakit terletak langsung di tanah atau di bawahnya tetapi dalam beberapa kasus pondasi rakit mungkin didukung oleh tiang (Mahmoud, 2015). Pada penelitian ini shelter tsunami menggunakan perencanaan pondasi rakit dengan metode konvensional (conventional rigid method). Tahapan perhitungan metode konvensional adalah: 
1. Menentukan letak resultan beban kolom (Q) terhadap sumbusumbu plat pondasi rakit ( $\mathrm{e}_{\mathrm{x}}$ dan $\mathrm{e}_{\mathrm{y}}$ ).

2. Menentukan klasifikasi tanah berdasarkan data sondir.

3. Menghitung daya dukung tanah (qult) berdasarkan klasifikasi tanah.

4. Menghitung tegangan kontak yang terjadi pada tanah di bawah masing-masing kolom (beban momen dan eksentris pada pondasi) pada gambar.

5. Bandingkan nilai tegangan kontak (q) yang dihitung dalam langkah (4) dengan kapasitas daya dukung tanah (qult), memenuhi syarat terhadap faktor keamanan (SF) atau tidak.

\subsection{Penelitian Terdahulu}

Pradana, Saputra, Indarto, \& Nurhuda (2015) menyatakan bahwa: pembangunan Tempat Evakuasi Sementara (TES) dapat menahan beban-beban yang terjadi akibat genangan tsunami yang terjadi, hal tersebut dapat terjadi dengan mempertimbangkan segala aspek beban yang timbul, sehingga bangunan dapat bertahan terhadap tsunami.

Adityawarman (2014) menyatakan bahwa kolom baja didesain dengan bentuk circular sehingga mengurangi gaya dorong pada kolom akibat aliran air.

Kukodime, Otake, Takane, Utsunomiya, \& Onami (2013) menyatakan bahwa Desain tubuh utama shelter termasuk desain strukturnya harus memperhatikan keamanan, kinerja tahan air, dan efisiensi konstruksi dari perlengkapan dan fasilitas lainnya, fasilitas dari bangunan dirancang dengan memperhatikan lingkungan pengungsian dan aktivitas evakuasi.

$$
\text { Brahman Industries }
$$
menciptakan tempat evakuasi untuk mitigasi bencana badai, tornado, dan tsunami yang memiliki misi untuk mengembangkan terobosan ini sebagai dalam rangka memberikan alternatif kesiapsiagaan utama, membawa ketenangan bagi banyak orang yang tinggal di lokasi yang rentan terhadap bencana alam seperti banjir, dan tsunami (Anonim, 2012).

$$
\text { Better Shelter.Org }
$$
menciptakan shelter dengan desain modular berarti bagian dapat ditambahkan dan dihapus untuk membuat struktur yang berbeda, dalam konteks respons bertahap, unit ini dapat ditingkatkan menggunakan materi lokal, mudah dirawat, dan komponen dapat dengan mudah diganti jika terjadi kerusakan. Itu bisa dibongkar, 
dipindahkan, dan dipasang kembali (Anonim, 2015a).

\section{METODE PENELITIAN}

Penelitian dilaksanakan di TPI (Tempat Pelelangan Ikan) Satelit, Dusun Palurejo, Tembokrejo, Kabupaten Banyuwangi, Jawa Timur yang merupakan salah satu wilayah dengan indeks tinggi pada tingkat kerawanan tsunami dan merupakan tempat pusat ekonomi yang padat serta sangat berisiko tinggi di Kota Banyuwangi. Penentuan lokasi penelitian ini juga digunakan untuk merencanakan desain pondasi dan respon spektrum gempa pada shelter tsunami. Metode penelitian ditunjukkan pada Gambar 1.

Secara umum, penelitian ini dilakukan dengan metode penelitian berbasis trial and error, apabila kontrol belum memenuhi syarat maka dilakukan penentuan ulang data perencanaan struktur baja dan pondasi.

\section{HASIL DAN PEMBAHASAN}

\subsection{Data Perencanaan}

Adapun data spesifik perencanaan kontruksi bangunan shelter yang digunakan pada penelitian ini adalah:

1. Struktur bangunan: Bangunan Baja.

2. Mutu Baja: BJ 37.
3. Tegangan Leleh $\left(f_{y}\right): 2,400$ $\mathrm{kg} / \mathrm{cm}^{3}$.

4. Tegangan Ultimit $\left(f_{u}\right): 3,700$ $\mathrm{kg} / \mathrm{cm}^{3}$.

5. Berat jenis baja: $7,850 \mathrm{~kg} / \mathrm{cm}^{3}$.

6. Modulus elastisitas baja: 200,000 $\mathrm{kg} / \mathrm{cm}^{3}$.

7. Dimensi bangunan: $15 \mathrm{~m} \mathrm{x} 5 \mathrm{~m} \mathrm{x}$ $4 \mathrm{~m}$.

8. Jenis Profil : Wide Flange (IWF).

9. Koefisien muai panjang : $12 \mathrm{x}$ $10-6 /{ }^{\circ} \mathrm{C}$.
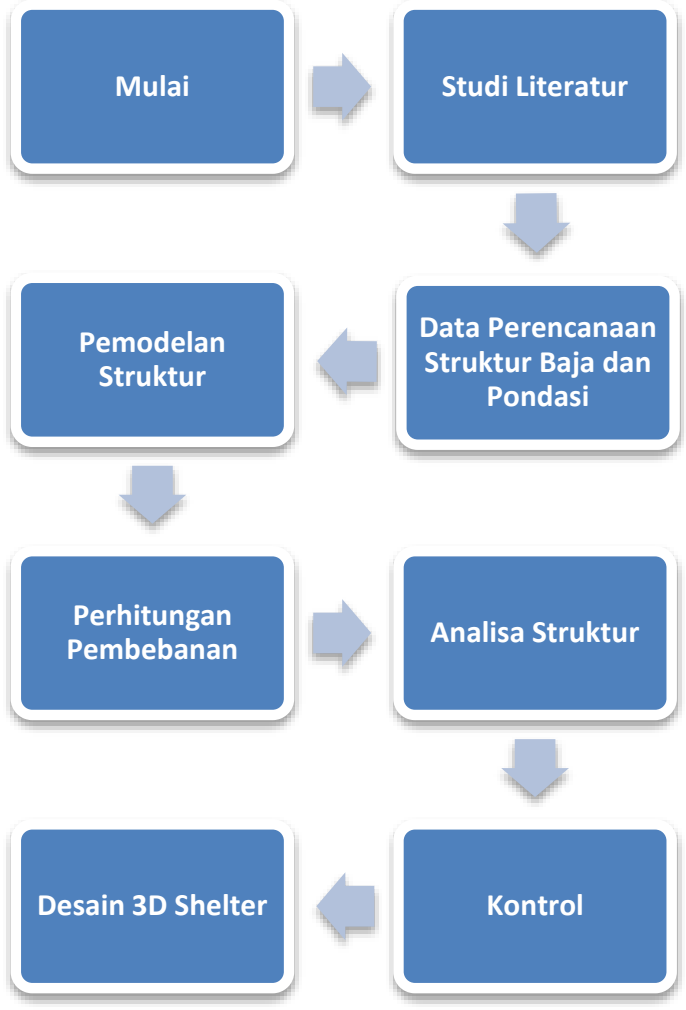

Hasil dan

Pembahasan

Gambar 1. Bagan Alir Metodologi Penelitian 


\subsection{Pemodelan Struktur}

Untuk memudahkan pemodelan struktur bangunan yang akan difungsikan sebagai tempat evakuasi sementara (TES), digunakan software untuk memudahkan analisis dan desain pada struktur bangunan secara 3D dengan efisien. Pemodelan struktur shelter ditunjukkan pada Gambar 2.

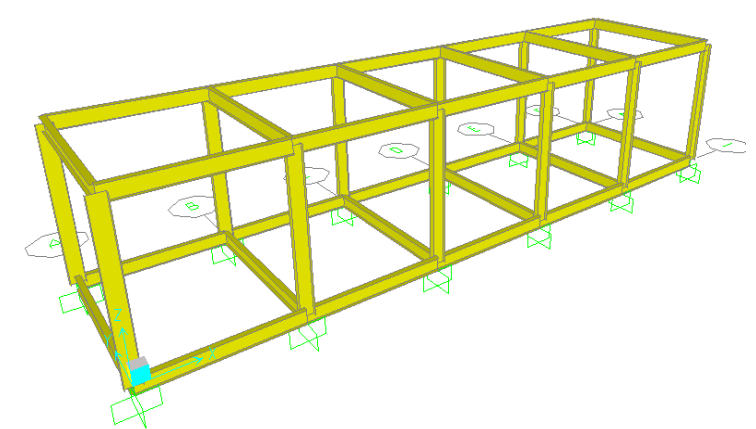

Gambar 2. Pemodelan Struktur Shelter

\subsection{Perhitungan Pembebanan Struktur}

Dalam analisa pembebanan pada struktur ini kombinasi pembebanan digunakan berdasarkan Spesifikasi Untuk Bangunan Gedung Baja Struktural (SNI 031729-2015), Beban Minimum Untuk Perancangan Bangunan Gedung Dan Struktur Lain (SNI 03-1727-2013), Tata Cara Perencanaan Ketahanan Gempa Untuk Struktur Bangunan Gedung Dan Non Gedung (SNI 03-1726-2019). Perhitungan pembebanan pada struktur bangunan shelter dilakukan menggunakan bantuan program aplikasi komputer sehingga mempermudah perhitungan struktur dan mendapatkan hasil yang lebih akurat.

\subsubsection{Beban Pelat Atap}

Beban yang bekerja pada pelat disalurkan menuju balok, kolom dan menjadi beban tambahan yang harus dipikul oleh balok induk maupun balok anak. Berikut beban pada pelat atap yang bekerja.

Beban yang bekerja meliputi beban mati, beban hidup, dan dapat dilihat pada Gambar 3 dan Gambar 4. Rekapitulasi pembebanan pelat atap ditunjukan pada Tabel 1.

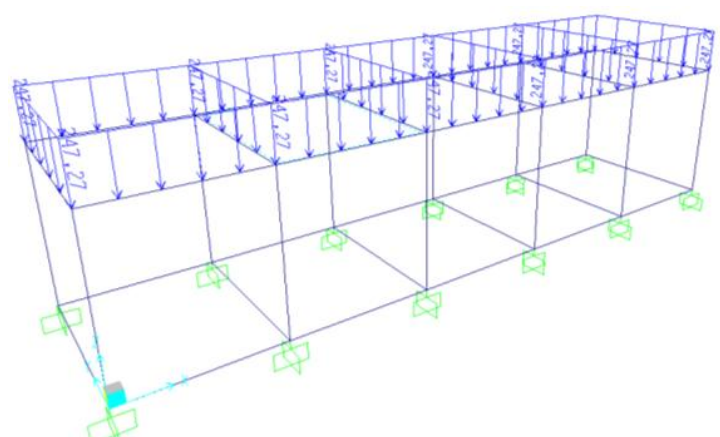

Gambar 3. Pemodelan Beban Mati

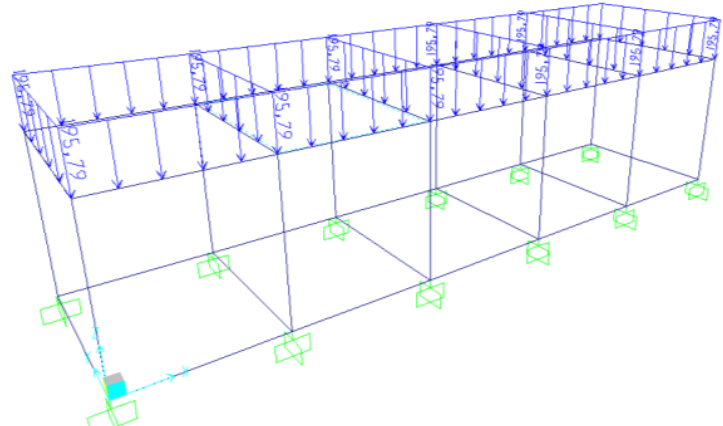

Gambar 4. Pemodelan Beban Hidup 


\subsubsection{Beban Angin}

Beban angin ditentukan dengan menganggap adanya tekanan positif dan tekanan negatif yang bekerja tegak lurus pada bidang-bidang yang ditinjau. Besarnya tekanan tiup harus diambil minimum $25 \mathrm{~kg} / \mathrm{m}^{2}$, kecuali untuk bangunan dengan tekanan tiup di tepi laut hingga $5 \mathrm{~km}$ dari pantai harus diambil minimum 40 kg/m² (Anonim, 2013). Berdasarkan tujuan dari shelter untuk tempat evakuasi sementara yang telah disebutkan minimal berjarak 500 meter dari pantai maka besarnya beban angin diambil $40 \mathrm{~kg} / \mathrm{m}^{2}$. Pemodelan beban angin ditunjukkan pada Gambar 5.

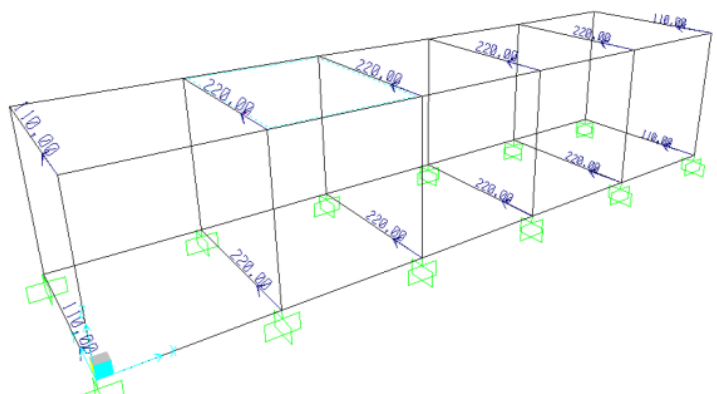

Gambar 5. Pemodelan Beban Angin

Tabel 1. Rekapitulasi Pembebanan

\begin{tabular}{|c|c|c|c|}
\hline \multirow{3}{*}{ Lokasi } & \multicolumn{3}{|c|}{ Jenis Beban } \\
\hline & \multicolumn{2}{|c|}{ Beban Matie $\left(\mathrm{Kg} / \mathrm{m}^{2}\right)$} & \multirow{2}{*}{ Beban Hidup $\left(\mathrm{Kg} / \mathrm{m}^{2}\right)$} \\
\hline & Beban mati & Beban mati tambahan & \\
\hline Pelat Atap & 215 & 32.27 & 195.78 \\
\hline Total & \multicolumn{2}{|c|}{247.27} & 195.78 \\
\hline
\end{tabular}

\subsubsection{Beban Gempa}

Persyaratan struktur bangunan tahan gempa adalah kemungkinan terjadinya risiko kerusakan pada bangunan merupakan hal yang dapat diterima, tetapi keruntuhan total (collapse) dari struktur yang dapat mengakibatkan terjadinya korban yang banyak harus dihindari. Perhitungan beban gempa menggunakan SNI 03-1726-2019 dengan metode respon spektrum (Anonim, 2019).

Response spectrum function definition digunakan untuk memasukkan data pada pemodelan struktur. Data tersebut berupa nilai koordinat untuk grafik respon spektrum disajikan dalam grafik antara nilai waktu dalam detik terhadap koefisien percepatan dalam g. Data tersebut berupa nilai spektral percepatan di permukaan gempa yang berlokasi di TPI Satelit, Muncar, Banyuwangi yang didapatkan dari situs Pusat Penelitian dan Pengembangan Perumahan Kementerian PU (Anonim, 2009b). Data tersebut kemudian di input pada software dengan nilai sesuai tanah yang dipilih atau ditentukan dimana digunakan tanah keras. Grafik nilai yang telah diinput pada software ditunjukkan pada Gambar 6. 


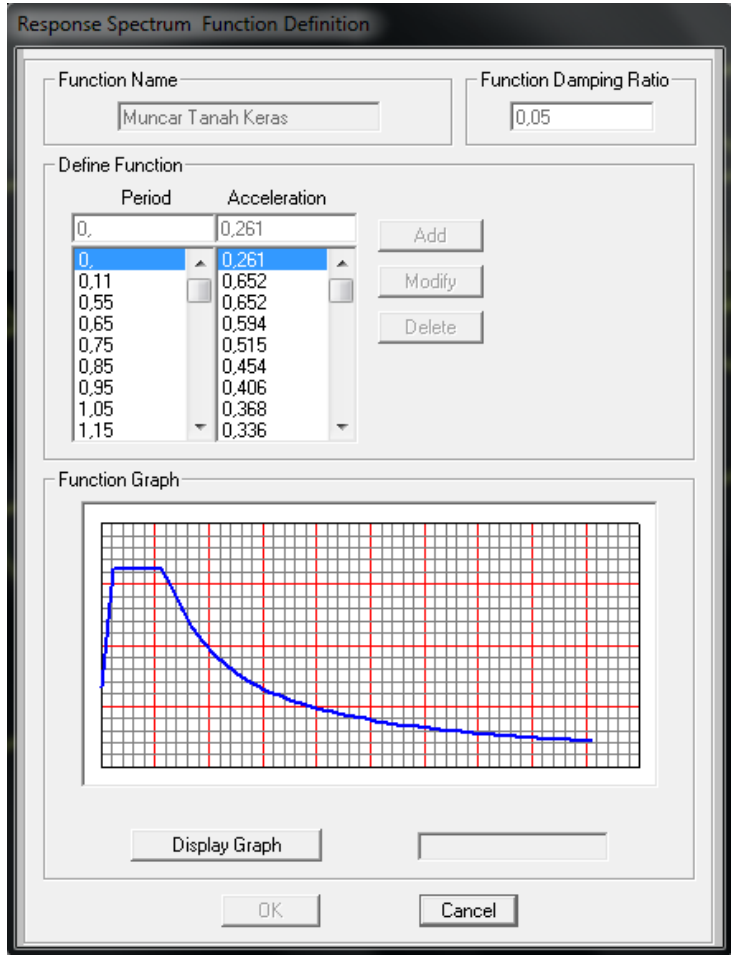

Gambar 6 Grafik Respon Spektrum

\subsubsection{Beban Tsunami}

Beban tsunami yang diperhitungkan dalam desain struktur gedung evakuasi sementara hanyalah gaya hidrodinamik, gaya impulsif, gaya tahanan debris atau hanyutan puing dan gaya tumbukan debris dengan perhitungan sebagai berikut:

1. Elevasi design runup height $(\mathrm{R})=$ $6 \mathrm{~m}$

2. Elevasi \pm 0.00 gedung $(\mathrm{z})=3 \mathrm{~m}$

3. Tinggi kolom pada lantai $1(\mathrm{hc})=$ $3.5 \mathrm{~m}$

4. Percepatan gravitasi (g) $=9.81$ $\mathrm{m} / \mathrm{det}^{2}$

\subsubsection{Gaya Hidrodinamik}

$$
\begin{aligned}
& F_{d}=1 / 2 \cdot \rho_{s} \cdot C_{d} \cdot B \cdot\left(h u^{2}\right)_{\text {max }} \\
& F_{d}=51914.52 \mathrm{~kg}
\end{aligned}
$$

\subsubsection{Gaya Impuls}

$$
\begin{aligned}
& \text { Fs }=1.5 \cdot \mathrm{Fd} \\
& \text { Fs }=1.5 \cdot 51914.52 \mathrm{~kg} \\
& F s=77871.78 \mathrm{~kg}
\end{aligned}
$$

\subsubsection{Gaya Tahanan Debris atau Hanyutan Puing

$$
\begin{aligned}
& F_{d m}=1 / 2 \cdot \rho_{s} \cdot C_{d} \cdot B_{d} \cdot\left(h u^{2}\right)_{\text {max }} \\
& F_{d m}=59330.88 \mathrm{~kg}
\end{aligned}
$$

\subsubsection{Gaya Tumbukan Debris atau Hanyutan Puing}

1. Batang Kayu

$$
\begin{aligned}
& \mathrm{F}_{\mathrm{i}}=\mathrm{C}_{\mathrm{m}} \cdot \mathrm{U}_{\max } \sqrt{(\mathrm{k} \cdot \mathrm{m})} \\
& \mathrm{F}_{\mathrm{i}}=504.26 \mathrm{kN}
\end{aligned}
$$

2. 20ft Heavy Shiping Container

$$
\begin{aligned}
& \mathrm{F}_{\mathrm{i}}=\mathrm{C}_{\mathrm{m}} \cdot \mathrm{U}_{\max } \sqrt{(\mathrm{k} \cdot \mathrm{m})} \\
& \mathrm{F}_{\mathrm{i}}=980.10 \mathrm{kN}
\end{aligned}
$$

\subsection{Analisa Struktur}

Analisa struktur dilakukan dengan menggunakan program aplikasi komputer agar mempermudah perhitungan pembebanan. Gaya-gaya dalam dihasilkan dari analisa ditinjau secara keseluruhan dan setiap elemen. Dari data hasil analisa tersebut kemudian dikontrol secara manual mengacu pada SNI 03-1729-2015. Gayagaya dalam struktur keseluruhan ditunjukkan pada Error! Reference source not found.. 
Tabel 2. Gaya-gaya dalam struktur keseluruhan

\begin{tabular}{c|c|c|c}
\hline & $\begin{array}{c}\mathbf{P} \\
(\mathbf{k N})\end{array}$ & $\begin{array}{c}\mathbf{V 2} \\
(\mathbf{k N})\end{array}$ & $\begin{array}{c}\text { M3 } \\
(\mathbf{k N}-\mathbf{m})\end{array}$ \\
\hline Maksimum & -926.734 & 674.86 & -410.8485 \\
\hline Minimum & 76.374 & -674.86 & 410.8002 \\
\hline
\end{tabular}

\subsubsection{Perencanaan Struktur Balok}

Mencoba perhitungan struktur balok menggunakan data penampang yaitu profil baja IWF 350x350x19x19. Pemeriksaan Interaksi Lentur dan Geser:

$$
\begin{aligned}
& \frac{\mathrm{M}_{\mathrm{u}}}{\phi_{\mathrm{b}} \cdot \mathrm{M}_{\mathrm{n}}}+0.625 \times \frac{\mathrm{V}_{\mathrm{u}}}{\phi \cdot \mathrm{V}_{\mathrm{n}}}<1.375 \\
& 1,19<1.375 \Longrightarrow 0 \mathrm{OK} !
\end{aligned}
$$

\subsubsection{Perencanaan Struktur Kolom}

Mencoba perhitungan struktur balok menggunakan data penampang yaitu profil baja IWF 350x350x19x19. Kekuatan Tekan Desain:

$$
\begin{aligned}
& \frac{\mathrm{P}_{\mathrm{u}}}{\phi . \mathrm{P}_{\mathrm{n}}}<1 \\
& \frac{926.7}{0.9 \times 4,507.28}<1 \rightarrow 0.228<1.0 \Longrightarrow \mathrm{OK} !
\end{aligned}
$$

\subsubsection{Perencanaan Pondasi Rakit}

Perencanaan berdasarkan pengujian sondir atau Cone Penetrometer Test yang dilakukan di TPI Satelit, Muncar, Banyuwangi sampai kedalaman 12.4 meter. Tekanan pada tanah:

$$
\begin{aligned}
\mathrm{q} & =\frac{\mathrm{Q}}{\mathrm{A}}=\frac{38,971.9}{64}=608.936 \mathrm{~kg} / \mathrm{m}^{2} \\
& =0.061 \mathrm{~kg} / \mathrm{cm}^{2}
\end{aligned}
$$

Cek:

$$
\begin{aligned}
& \mathrm{q}<\mathrm{Q}_{\text {all }} \\
& 0.061<1.188 \mathrm{~kg} / \mathrm{cm}^{2} \Rightarrow \mathrm{OK} !
\end{aligned}
$$

\subsubsection{Desain 3D Shelter}

Struktur bangunan shelter dengan dimensi 16 m x 4 m x 3.5 m dimodelkan dalam 3D menggunakan aplikasi komputer setelah dilakukan analisis struktur sesuai dengan spesifikasi untuk bangunan gedung baja struktural yaitu SNI 03-1729-2015 (Anonim, 2015b).

Adapun bagian yang ditinjau adalah semua elemen struktur yang meliputi kolom dan balok yang dapat dilihat pada Gambar 7 serta denah dan desain shelter secara utuh dapat dilihat pada Gambar 8 dan Gambar 9.

\subsubsection{Lokasi Rencana Shelter}

Dalam menentukan area evakuasi digunakan peta bahaya tsunami. Adapun syarat lokasi shelter ialah (Muhajir \& Agung, 2013):

1. Berada dekat jalur evakuasi

2. Berada pada konsentrasi penduduk

3. Lahan yang telah ditetapkan

4. Fasilitas umum

Sarana yang digunakan dalam melakukan evakuasi tsunami yakni tiaptiap ruas jalan yang masih didalam area batas bahaya tsunami. Dengan demikian, area evakuasi vertikal dapat ditentukan dengan menghitung sejauh dari mana seseorang dapat mencapai lokasi tersebut 
dalam waktu evakuasi yang tersedia. Untuk mendapatkan lokasi ini, maka digunakan tool service area yang tersedia pada ekstensi Network Analyst.

Service Area Analyst digunakan untuk menemukan area yang dapat diakses dari suatu titik yang ada pada suatu jaringan jalan. Sebuah layanan jaringan merupakan wilayah yang mencakup semua jalan-jalan yang diakses. Pada Algoritma Dijkstra node digunakan karena menggunakan diagram pohon untuk menentukan jalur lintasan terpendek dari node asal ke node terdekat, kemudian ke node berikutnya dan seterusnya (Afandi \& Purwaningsih, 2019).

Menentukan wilayah jangkauan yang dihitung berdasarkan waktu kecepatan berlari masyarakat saat terjadi tsunami menuju shelter di kecamatan Muncar menggunakan service area analyst. Berdasarkan analisis yang dilakukan didapatkan 3 titik lokasi shelter yakni di desa tembokrejo, desa kedungrejo, dan desa kedungwringin.

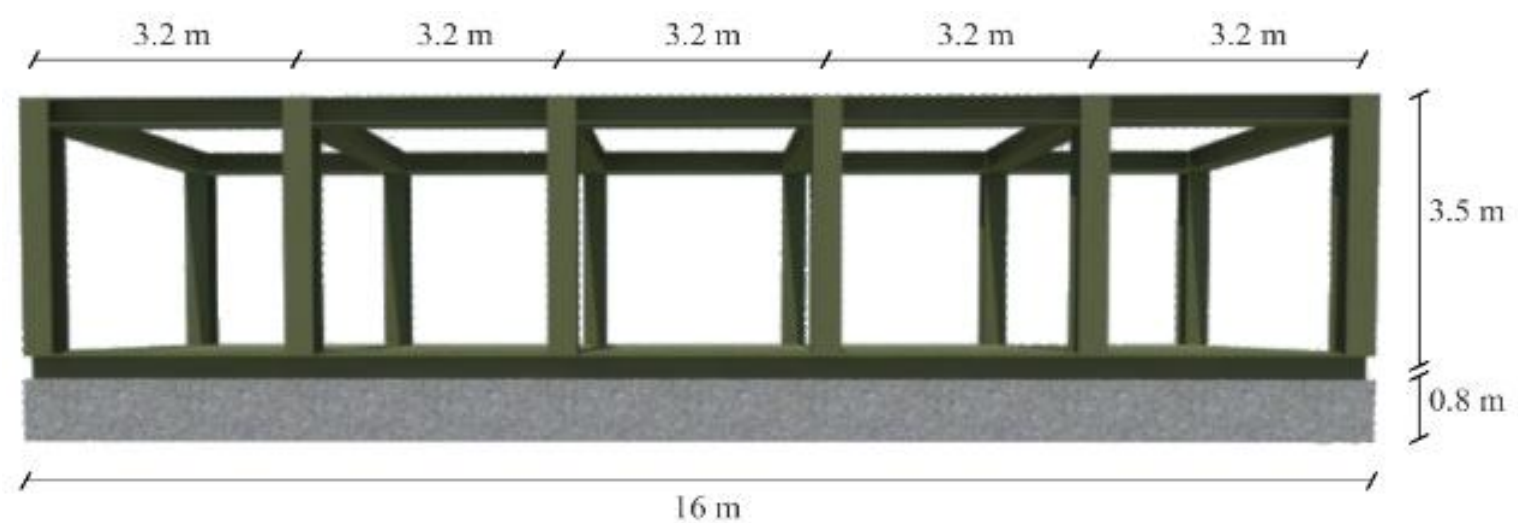

Gambar 7. Kerangka shelter

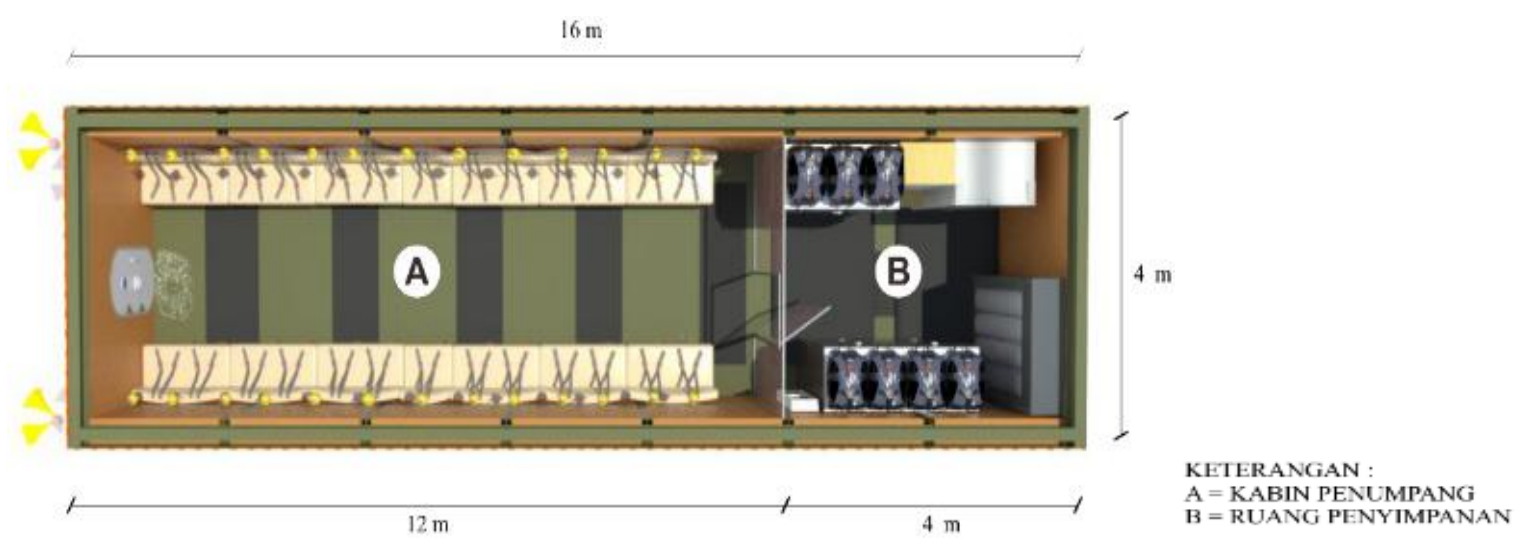

Gambar 8. Denah Shelter 


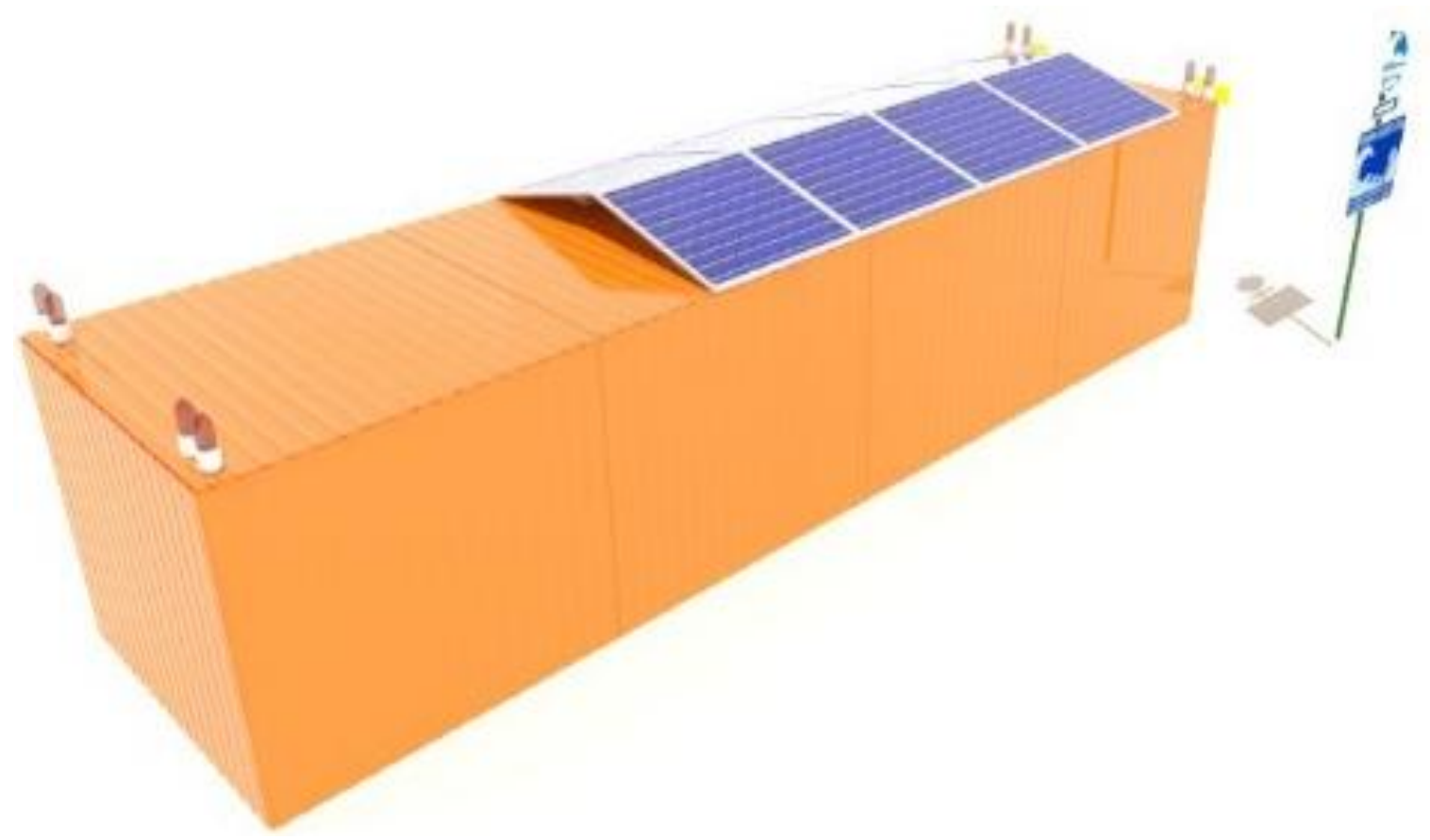

Gambar 9. View 2

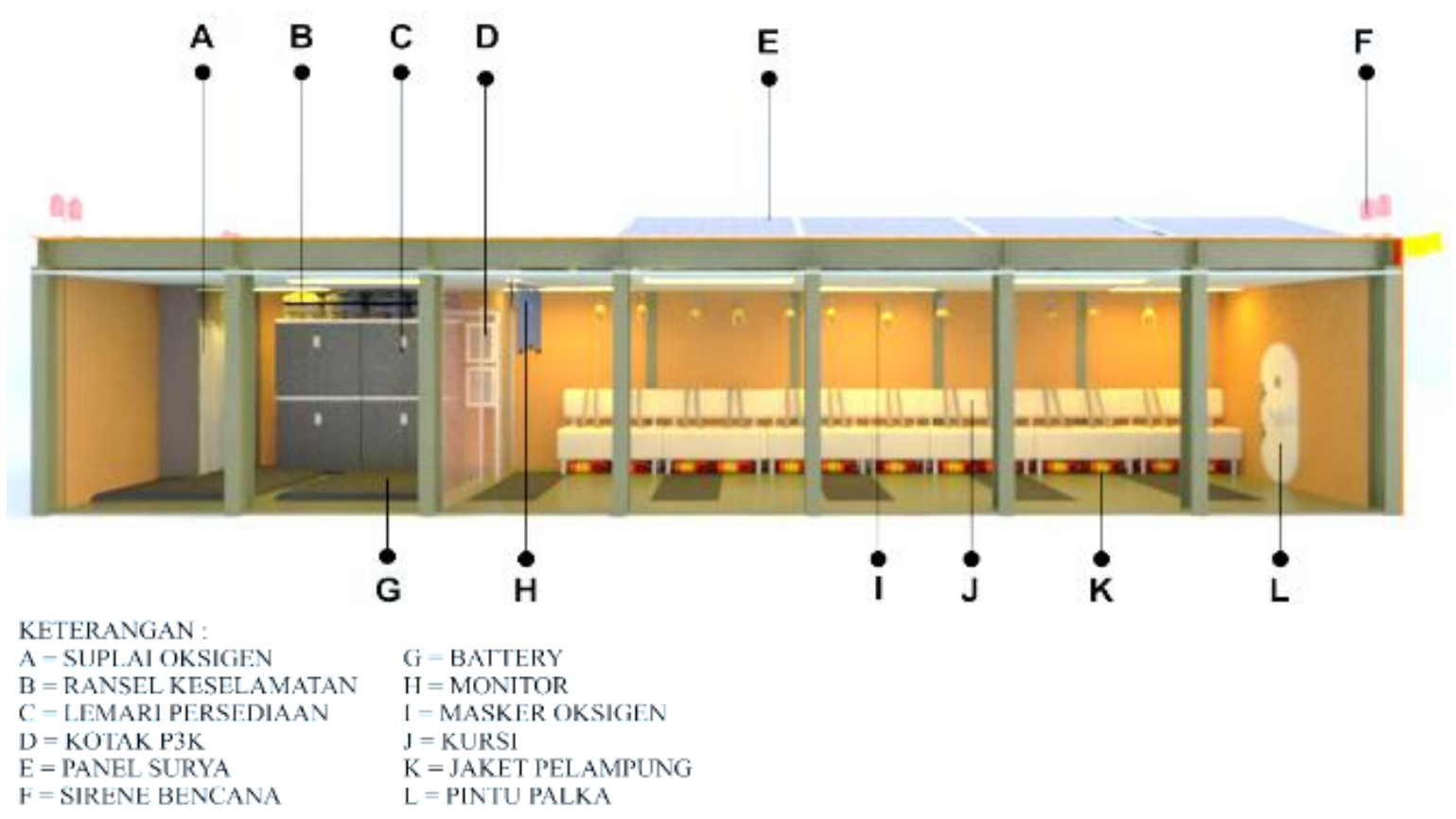

Gambar 10. Interior Tampak Samping

\subsubsection{Inovasi Shelter}

Pada penelitian ini shelter didesain untuk multifungsi atau multi purpose, digunakan sehari-hari yang difungsikan sebagai pusat kesehatan khusus atau unit perawatan intesif untuk nelayan atau warga sekitar yang mengalami kecelakaan ringan dengan disediakannya perlengkapan pertolongan pertama untuk korban kecelakaan seperti kotak P3K, dan suplai 
oksigen. Untuk memenuhi kebutuhan listrik didalam shelter digunakan panel surya yang memanfaatkan energi matahari dan energi cadangan listrik disimpan pada baterai yang tersimpan dibawah dek lantai, serta terdapat fasilitas keselamatan lainnya yang cukup lengkap seperti ransel keselamatan, jaket pelampung, suplai oksigen, monitor, telepon satelit dan perlengkapan lain sebanyak 12 jenis untuk tujuan utama dari shelter yang disajikan pada Gambar 10. Pada shelter juga terdapat sirene bencana yang akan berbunyi saat diumumkannya bencana tsunami oleh BMKG, pada masa tersebut masyarakat diwajibkan untuk melakukan evakuasi ke dataran tinggi atau shelter yang tersedia serta menggunakan jaket pelampung dan sabuk keselamatan atau safety belt untuk menghindari cedera pada saat kemungkinan shelter terguling. Dalam proses pembangunannya bangunan shelter dapat dipindah-pindah (mobile) sehingga dapat memenuhi kebutuhan shelter di setiap daerah dengan cepat.

\section{SIMPULAN DAN SARAN}

\subsection{Simpulan}

Desain struktur shelter inovatif berbasis tempat evakuasi sementara di Banyuwangi dengan mengacu pada spesifikasi untuk bangunan gedung baja struktural (SNI 03-1729-2015), dapat disimpulkan bahwa shelter inovatif dengan dimensi $16 \mathrm{~m} \times 4 \mathrm{~m} \times 3.5 \mathrm{~m}$, pada balok menggunakan profil baja IWF 350.350.19.19 dan kolom menggunakan IWF 350.350.19.19 dengan berat struktur shelter sebesar 38292.9 Kg. Hasil perencanaan struktur balok dengan kontrol pemeriksaan interaksi lentur dan geser sebesar 1.19 harus kurang dari interaksi lentur dan geser ijin sebesar 1.375, perencanaan struktur kolom dengan kontrol pemeriksaan kekuatan tekan desain sebesar 0.228 harus kurang dari kekuatan tekan desain ijin sebesar 1. Pondasi rakit direncanakan dengan dimensi $16 \mathrm{~m}$ x $4 \mathrm{~m}$ dan disarankan dengan ketebalan $80 \mathrm{~cm}$ dengan kontrol tekanan pada tanah sebesar $0.061 \mathrm{Kg} / \mathrm{cm}^{2}$ harus kurang dari daya dukung tanah sebesar $0.188 \mathrm{Kg} / \mathrm{cm}^{2}$, shelter didesain untuk multifungsi atau multi purpose, digunakan sehari-hari yang difungsikan sebagai pusat kesehatan khusus atau unit perawatan intesif dengan fasilitas keselamatan yang cukup lengkap seperti ransel keselamatan, pelampung, suplai oksigen, telepon satelit dan perlengkapan lain untuk tujuan utama dari shelter.

\subsection{Saran}

1. Penelitian selanjutnya adalah dengan melakukan rekayasa sirkulasi udara dan pencahayaan secara alami pada shelter. 
2. Selanjutnya dapat dilakukan pengembangan dan rekayasa fungsional shelter untuk fungsi kemanusiaan lainnya.

\section{DAFTAR PUSTAKA}

Adityawarman, G. M. (2014). Perencanaan Bangunan Evakuasi di Wilayah Rawan Gempa dan Tsunami. Jurnal Kajian Teknologi, 10(2), 110-119.

Afandi, Y., \& Purwaningsih, E. (2019). Rencana Lokasi Shelter Evakuasi Tsunami di Kecamatan Tanjung Mutiara Kabupaten Agam. Jurnal Kapita Selekta Geografi, 2(1), 15-22. https://doi.org/https://doi.org/10.240 36/ksgeo.v2i1.135

Anonim. (2009a). FEMA P646: Vertical Evacuation from Tsunamis. California: Federal Emergency Management Agency.

Anonim. (2009b). Pedoman Perencanaan Umum Pembangunan Infrastruktur di Kawasan Rawan Tsunami. Jakarta: Kementerian Pekerjaan Umum.

Anonim. (2012). STATIM Shelters. Retrieved from Brahman Industries website: www.statimshelter.com

Anonim. (2013). SNI 03-1727-2013 tentang Beban Minimum untuk Perancangan Bangunan Gedung dan Struktur Lain. Jakarta: Badan Standardisasi Nasional.

Anonim. (2015a). Better Shelter 1.2. Retrieved from bettershelter.org website: www.bettershelter.org

Anonim. (2015b). SNI 03-1729-2015 tentang Spesifikasi untuk Bangunan Gedung Baja Struktural. Jakarta: Badan Standardisasi Nasional.

Anonim. (2016). Penurunan Indeks Risiko
Bencana di Indonesia. Jakarta: Badan Nasional Penanggulangan Bencana.

Anonim. (2019). SNI 03-1726-2019 tentang Tata Cara Perencanaan Ketahanan Gempa untuk Struktur Bangunan Gedung dan Nongedung. Jakarta: Badan Standardisasi Nasional.

Hutapea, E. (2019). Properti Kompas. Retrieved from www.properti.kompas.com

Kukodime, Otake, Takane, Utsunomiya, \& Onami. (2013). Detailed Design of Tsunami Shelter. Tokyo: Eventscribe.

Mahmoud, H. (2015). Design of MAT or Raft Foundation. Retrieved from https://drive.uqu.edu.sa/hmmostafa/fi les/10 raft.pdf

Muhajir, A., \& Agung, N. C. (2013). Analisis Persebaran Bangunan Evakuasi Bencana Tsunami Menggunakan ArcGIS. Surabaya: Teknik Geomatika, Fakultas Teknik dan Perencanaan, Institut Teknologi Sepuluh November.

Pradana, A. B., Saputra, R. P., Indarto, H., \& Nurhuda, I. (2015). Desain Struktur Tempat Evakuasi Sementara di Bengkulu. Jurnal Karya Teknik Sipil, 4(4), 69-84.

Rifqi, M. G., Amin, M. S., \& Sandi, E. A. (2019). Rancang Bangun Tsunami Pods Sebagai Tempat Evakuasi Sementara (TES) Untuk Mewujudkan Wilayah Tangguh Bencana. Potensi: Jurnal Sipil Politeknik, 21(2), 74-82. https://doi.org/10.35313/potensi.v21i 2.1670 